\title{
Interpreting the Anger of President Joko Widodo: An Analysis in the Perspective of Javanese Political Culture
}

\author{
Wijayanto ${ }^{1}$, Nurul Hasfi ${ }^{2}$ \\ \{wijabaru@gmail.com ${ }^{1}$ \} \\ Universitas Diponegoro, Indonesia ${ }^{1,2}$
}

\begin{abstract}
This study aims to reveal the meaning of President Jokowi's anger in the last June 2020 following the poor performance of his cabinet in handling the COVID 19 pandemic in the perspective of Javanese culture. Some questions to be answered are: How can Jokowi's anger be interpreted in the perspective of Javanese culture, where the president grew and formed his habitus? What is the attitude of a leader when angry in Javanese culture? Is this anger a reflection of the wisdom of the leader who defends the underprivileged or is it an indication of his power is increasingly weakened? These questions will be answered through media text analysis methods. In this case, the text as the object of analysis is twofold: written text in the form of media coverage and audiovisual text in the form of a video of the President's anger on YouTube that shows voice, facial expressions and body language as well as Joko Widodo. This study argues that Jokowi's anger reflects the weakening of his power as a president who are surrounded by oligarchic elites who are now competing for their own political interest to win political stages to secure their positions after the end of Jokowi's presidential second term.
\end{abstract}

Keywords: Anger, President, Political Culture, Java

\section{Introduction}

This study aims to reveal the meaning of President Jokowi's anger in the last June 2020 (Kompas, 29 June 2020) following the poor performance of his cabinet in handling the COVID 19 pandemic in the perspective of Javanese culture. This anger was shown in front of a cabinet meeting attended by his ministers. Since the beginning of the entry of the coronavirus in Indonesia, the ministers who were considered reliable as the main parties in handling corona were deemed not showing good performance. Over time, there has also been no significant performance improvement in handling corona in Indonesia. This has sparked the anger of President Jokowi, who has only been shown after almost more than one term in office.

President Jokowi's intense anger is a rare event that rarely occurs. Because we remember, President Jokowi is a Javanese from Solo who is famous for his hospitality, who is very "Javanese" suddenly angry so much with an expression that is unusually different from usual. In Javanese culture, when angry, it refers to their feelings, which because Javanese culture places great importance on "rasa" and consideration of feelings. 


\section{Research Questions}

Based on the description of the research background above, this study aims to answer the following questions:

a) How do we interpret Jokowi's anger in the perspective of Javanese culture, where the president grows and forms his habitus?

b) What is the attitude of a leader when angry in Javanese culture?

c) Is this anger a reflection of the leader's wisdom in defending the little people or is it an indication of the waning "pulung" of a leader who is slowly stepping down from his position?

\section{Method}

To answer the questions above, this study uses text media analysis method. In this case, the text that becomes the object of analysis is twofold: written text in the form of media coverage and audio-visual text in the form of a video of the President's anger on YouTube which shows Joko Widodo's voice, facial expression and body language.

\section{Theoretical Framework}

To understand the meaning of Jokowi's anger, it is important to first understand what power means in Javanese culture. According to Anderson [1], power is seen as concrete, homogenous, constant and doesn't raise the question of legitimacy in Javanese culture. Central to this understanding, power comes from the divine source in the universe and not from the legitimacy of the people such as in western concept. In this regards, whether or not the divine source still wanted a king to be in power can be seen from the harmony in social life. This is because the social life in the world is seen as the reflection of the macro cosmos in which the divine power comes from. Furthermore, the Javanese believes that the nature of the universe is the order and harmony on cosmos; both in the macro and micro level. Therefore, they believe that to create a good life they have to keep the cosmos in harmony and order.

To further explain in a more detailed, there are two main concepts important for the maintenance of harmony in cosmos [2]: rukun (harmony) and hormat (respect). Rukun is an ideal situation that every Javanese person expects to emerge in every social relationship: family, neighbours, villages and also the work environment. It is also defined as "feeling in a state of harmony", "calm and peace", "without fighting or strife", "helping each other for the same purpose". Furthermore, it is a situation in which social relations are characterized by the absence of conflict, so it is often interpreted as a "principle" of avoiding conflict. What is emphasized in this case is not the absence of conflict itself, but it does not raise the conflict on the surface. This is because for Javanese people, the social situation is naturally peaceful. Meanwhile, hormat is a belief that all social relations have been arranged hierarchically and that social hierarchy is believed to be something good and, therefore, maintaining that social order is a moral imperative.

In addition to rukun and hormat, there is also a concept of rasa that is vital to maintain harmony. Geertz [3] suggested that rasa has two meanings, feeling and meaning. As "feeling" it refers to one of the five senses - seeing, hearing, speaking, smelling and tasting, and in itself 
there are three aspects of "feeling" which are separated by our view of the five senses: taste on the tongue, touch on the body, and emotional "feelings" in the "heart" such as sadness and happiness. As "meaning", rasa is applied to words in letters, poetry, or even in general speech to convey the implicit messages and satire suggestions that are so important in Javanese communication and social relations. The meaning of refined taste in Javanese culture is that the stronger a Javanese person is, the more refined he will be in processing the taste. He will be more peaceful in his mind, which will show in his lair behavior.

The theoretical review above can be concluded as follows: first of all, power is homogenous, concrete, constant and comes from a divine source in the universe. Secondly, social harmony and social order in the world is the reflection of macro cosmos or divine power. Third, consequently, this is important for a Javanese to maintain social harmony and social order. As the representation of God or the divine power on the earth, a king has the most obligation to maintain this harmony. Consequently, he is the most person to be the most refined in his behavior in order not to disturb the harmony. This also makes him the most powerful.

\section{Findings and Discussion}

This part will analyse the anger of President Jokowi in three important aspects: the language that he used, the tone of his voice and his non-verbal expression.

First of all, in term of language, there was an interesting sight at the plenary cabinet meeting of President Jokowi and his ministers which was held on June 18, 2020. At the meeting discussed the evaluation of policies and progress in handling the Covid-19 Pandemic. At that time, the president delivered his speech in a high tone that seemed to show his anger at his ministers in efforts to deal with Covid-19.

Jokowi said the atmosphere in the last three months was a crisis due to the outbreak of the coronavirus pandemic or Covid-19. However, the president sees that the ministers and leaders of other government agencies have yet to share in the face of a crisis situation. Jokowi assessed that they do not yet have the same frequency in terms of crisis sensitivity.

"I see, there are still many of us who are as normal. I was annoyed there. Don't you have feelings for this? This atmosphere is a crisis! ... Because this atmosphere must exist, this atmosphere, (if) you don't feel it, you will" (Kompas, 29 June 2020).

Typical Javanese culture places great importance on taste, so when angry, it is all about feelings. Here, Jokowi's disappointment can be seen with the slow and non-proactive response of his assistants. However, on the other hand, Jokowi's sentence also shows his inability to regulate and manage the performance of his ministers, because he cannot show strong control over his ministers as indicated by the gap between instructions and outputs obtained.

"I will take whatever extraordinary steps are, for our 267 million people, for the country. It is possible to dissolve the institution, it can also be reshuffled" (Kompas.com, 29/06/2020).

In the sentence of this speech, President Jokowi seemed to bully his ministers by threatening a reshuffle and dissolving government institutions. It is as if Jokowi shows that he has power over his ministers by using threatening sentences and language. 
Secondly, in term of tone it can be seen that Jokowi used a very loud tone, and he was unable to control his intonation. The volume of his voice and his intonation was so high unlikely any before.

This uncontrolled volume and tone went together with the uncontrolled expression of his face with so many changes in a very short period of time. This uncontrolled expression on his face and his gesture reflected that he was not in the situation of calm in his heart which is a reflection of a Javanese in power.

As discussed in the previous theoretical chapter, power in Javanese culture has its own principles. Some of them are respect, size, refinement of rasa. A Javanese leader will show respect for others, subordinates, and even opponents. A Javanese leader will also avoid conflict and prefer to maintain harmony in social relations and power. Which is as much as possible not to bring up or show the dispute to the surface. Because if disputes and conflicts appear on the surface, it will reduce their authority and power. In Javanese culture, a ruler also highly upholds the values and principles of refinement of taste. This can be demonstrated by speaking, using sentences, mimics, gestures, and in a subtle, orderly, and polite manner.

The hierarchy is also expressed in language usage. In general, Javanese people who have high strata and social status will use more refined language than ordinary people who are at lower strata. So that in Javanese culture, the higher a person's status and influence, the more refined the language used. More than that a person of high status will show a refined and polite character to anyone.

The language, tone and gesture of Jokowi reflected that his power is starting to weaken and fade. If he is still fully in power, he didn't need to express anger in such a refined way. As an example, we can look at the leadership in the era of President Soeharto. During the New Order era, President Soeharto was known as "The Smiling General". This predicate was pinned to Suharto because in his leadership, Pak Harto always showed nuances of harmony, harmony, hospitality, smiles, and refinement in his manner in front of the public and in his government. His refinement and leadership style in no way diminished his authority. In fact, it is very visible that his power and authority are very strong. This can be seen clearly in the body of his government where Suharto's role is very central and dominant. There is no government person under him who stands out. Everything is centralized to President Suharto.

Then another small example is when Suharto defended Kompas, Suharto just smiled and said briefly softly to Jacob Utama "ojo meneh-meneh". But it was ringing in the ears of Jacob Utama until 2015 when Kompas was 50 years old. Soeharto never showed his anger in public until it was uncontrollable, because in Javanese culture when a person cannot control his character and does not control the way he speaks, actually that person already weak in power. A strong leader does not need to threaten but just smile and speak softly one or two words but the words of Sabda Pandhita Ratu.

The weakening of a leader's power in Javanese culture usually has certain characteristics. One of them is the appearance of disharmony in the body of his government. If disharmony appears, it means that power is starting to wear off. Likewise, if harmony is still maintained, it means that the leader still has power over his government. This is the basis why the Javanese have a tendency to avoid conflict. This also reflects the sharpening of the dispute between the political elite who are looking for momentum and securing their position in 2024 when Jokowi can no longer run for president again. You can imagine there will be friction between the forces of the elite scrambling to start the campaign and secure themselves towards 2024 . 


\section{Conclusion}

In the perspective of Javanese political culture, the anger of President Jokowi, which was exposed openly in front of the public, can be read as a sign that his political power is weakening. This is also a reflection of the increasingly sharp clashes between the oligarchic elites around President Jokowi who were competing with each other to win the stage and power to secure their positions in 2024 when it is no longer possible for Jokowi to run for office. In the context of handling a pandemic, Jokowi's anger because he felt that his ministers were not carrying out his instructions increasingly emphasized the loss of control in handling pandemics which was one of the factors causing our failure to handle corona. The plan of cabinet reshuffle which was cancelled despite his previous threat actually emphasized Jokowi's weakness in front of his ministers and the elite coalition of Oligarch behind him.

\section{References}

[1] B. Anderson, “The idea of power in Javanese culture,” Cult. Polit. Indones., pp. 1-69, 1972.

[2] F. Magnis-Suseno, Javanese Etics and World-View. The Javanese Idea of the Good Life. Penerbit PT Gramedia Pustaka Utama, 1997.

[3] C. Geertz, The religion of Java. University of Chicago Press, 1976. 